\title{
Abiotic Stress and Its Amelioration in Cereals and Pulses: A Review
}

\author{
J.S. Kang ${ }^{1 *}$, Harmeet Singh ${ }^{1}$, Gurbir Singh ${ }^{2}$, Harrajdeep Kang ${ }^{3}$, \\ Vajinder Pal Kalra ${ }^{1}$ and Jagroop Kaur ${ }^{1}$
}

${ }^{1}$ Department of Agronomy, Punjab Agricultural University, Ludhiana-144001, Punjab, India

${ }^{2}$ Graduate Research Assistant, Dept. of Forestry, College of Agricultural Sciences, Southern

Illinois University Carbondale, Illinois USA

${ }^{3}$ Department of Botany, GNGC, Ludhiana-141004, Punjab, India

*Corresponding author

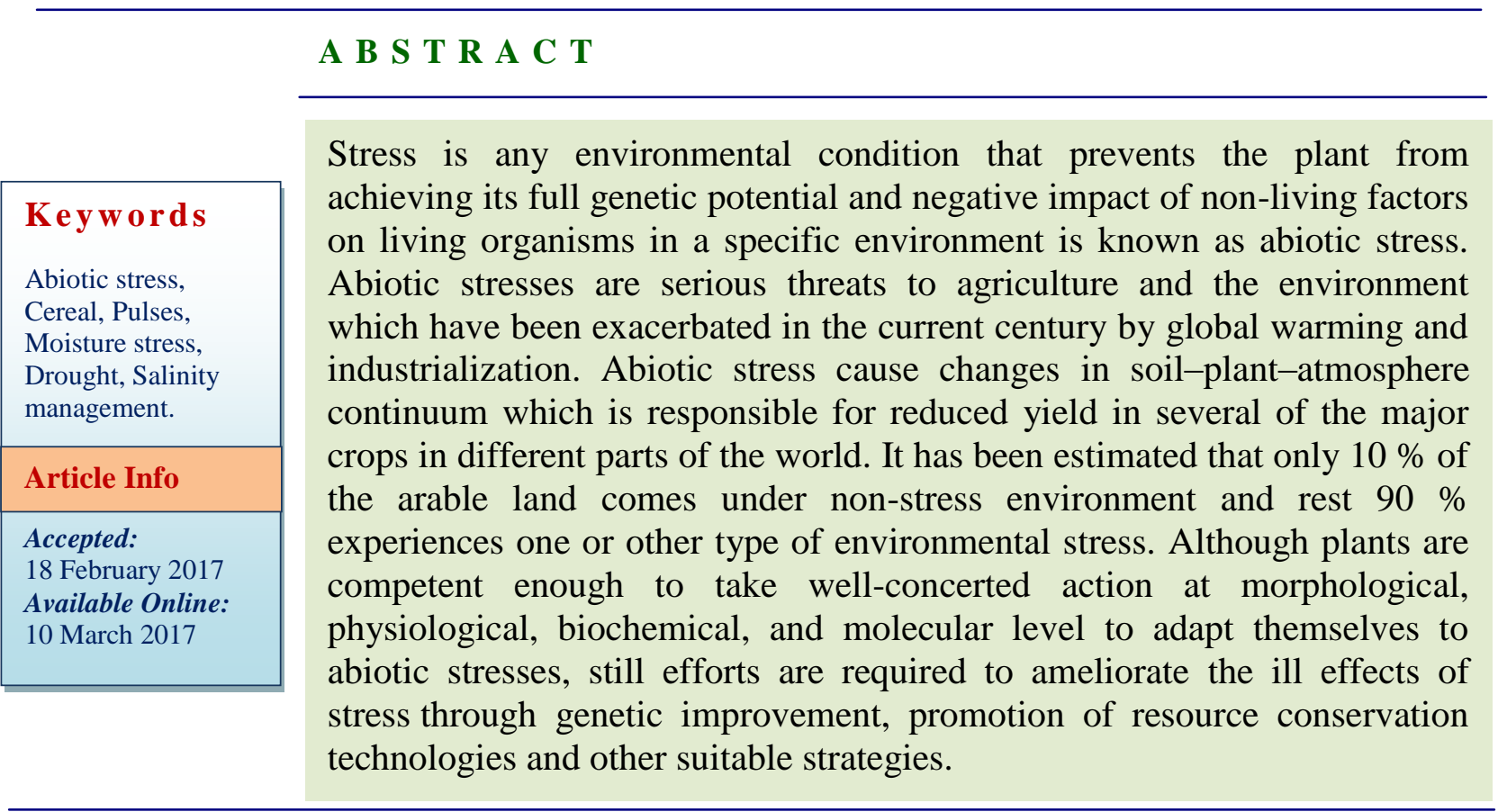

\section{Introduction}

The quality of produce, fiber, industrial end uses and suitability as food of crop is largely determined by not only modern production technologies but also optimum climatic conditions. Climate is a major factor in crop production but also the growth of plants obviously relies on modern production technologies The unfavorable climate with varying levels of stress would encourage scientist to select and breed varieties of crop having adaptation to such stresses. Worldwide, 70 per cent yield reduction is because of abiotic stresses (Acquadh 2007). Climate change is of great concern. Due to climate change, temperature is rising, rainfall pattern is uneven. So, our crop plants are experiencing various types of abiotic stresses. In many areas, rainfall is becoming less unpredictable due to increasing temperatures and in one such example of crop growing area 
in Africa (Segele and Lamb 2005), the pattern of receiving rainfall has drastically reduced the yield outputs (Seleshi and Camberlin 2006). Plants respond to stress and alter their metabolism in various ways and with a wide range of modifications leading to changes at morphological, cellular, physiological, biochemical, and molecular level and particularly by producing compatible solutes and organize proteins and cellular structures, maintaining cell turgor by osmotic alteration and modify the antioxidant system to reinstate the cellular redox balance and maintain internal stability.

\section{Abiotic stress in pulses}

Pulses can adapt to wide range of edaphic and climatic conditions and therefore can make up an an important component of climate-change mitigation and adaptation strategy. Major pulse crops in India include pigeonpea [Cajanus cajan (L.) Millsp.], urdbean [Vigna mungo (L.) Hepper], mungbean [Vigna radiata (L.) R. Wilczek], and cowpea [Vigna unguiculata (L.) Walp.] grown during the rainy (kharif) season (June-October) and chickpea (Cicer arietinum L.), lentil (Lens culinaris Medikus) and peas (Pisum sativum L.) grown during the winter (rabi) season (October-April). Abiotic stresses are primarily unavoidable and are the most detrimental factor concerning the growth, development and productivity of crops, especially under un-irrigated areas. The ability to tolerate effectively by challenging these stresses is a complicated phenomenon stemming out from various plant interactions occurring in the specific environments. The poor productivity of pulses in India is attributed primarily to poor spread of improved varieties and technologies, untimely and inadequate availability of quality seed of improved varieties and other inputs, water-stress due to dependence on rainfall, low and high temperature stress, vulnerability to pests and diseases and cultivation on insignificant and minor land. These crops are being grown as rainfed $(87 \%)$ on insignificant and minor lands which are recurrently prone to biotic and abiotic stresses. Abiotic stresses are occurring naturally and the role of agronomists can only work and plan of mitigation strategies for these stresses under varied climatic conditions for all the crops (Table 1).

\section{Response of pulses drought and moisture stress}

Brunt of moisture stress depends on duration and its intensity/severity and; prevents the crops from reaching the maximum yield. Nitrogen fixation, uptake and assimilation by leguminous plants are reduced due to reduction in leghaemoglobin in nodules and number of nodule under moisture-stress conditions. Depending on the level of stress, legumes suffer more for grain yield losses to a larger extent than shoot biomass diminution. Drought induced loss in crop yields exceeds losses from all other causes (Farooq et al., 2009) (Table 2). Terminal drought reduced seed yield of chickpea in a range of from 26 to $61 \%$. In addition, plant productivity is strongly affected by dry-matter production and its partitioning (Krishnamurthy et al., 2010). According to Lopez et al., (1996), long-duration pigeonpea experiences all the 3 types of drought, viz. early, intermittent and terminal. Understanding the physiological processes that happen during moisture stress is needed to ameliorate the stress effects either by management practices agronomically or alter the cropping pattern of the regions.

\section{Water logging stress response of pulses}

Water logging in short and as well as long term affects a number of biological and chemical processes in crop growth. 
Germinating seeds/ emerging seedlings are very sensitive to water logging, as their stage of metabolism is high during this period. Pulses are more sensitive to water logging than other crops. Flooding can trigger the incidence of soil-borne fungal diseases besides converting of $\mathrm{SO}_{4}$ to $\mathrm{H}_{2} \mathrm{~S}$ by anaerobic bacteria. Under waterlogging, growth is arrested and death takes place principally because demand for Adenosine triphosphate (ATP) molecules exceeds the supply and self-poisoning by products of anaerobic metabolism.

\section{Response of pulses to high temperature/ heat stress}

Optimum temperature of $10-25^{\circ} \mathrm{C}$ for cool season pulses and $15-30{ }^{\circ} \mathrm{C}$ for kharif pulses is required for better growth and development. Temperature above $25{ }^{\circ} \mathrm{C}$ caused heat stress in chickpea, field pea (Pisum sativum L.), faba bean (Vicia faba L.) and lentil, and $35-40{ }^{\circ} \mathrm{C}$ for rainy-season pulses, resulting $20-70 \%$ yield reductions through flower drop and pod abortion (Kumar et al., 2016). Soil moisture stress coupled with high temperature affects the growth and development of crop to a larger extent in dryland areas. Maheshwari et al., (2015) reported that high temperature in general harmfully affected photosynthesis, respiration process, cell water relations and membrane permanence, production of reactive oxygen species (ROS), and compatible solutes adjustment and accumulation of anti-oxidants compounds, etc. Pande and Sharma (2010) described in detail that increase in temperature and frequent moisture stress during flowering to pod-filling stage leads to severe infestation of dry root-rot [Rhizoctonia bataticola (Taubenh.) E.J. Butler] in chickpea (gram), especially under rainfed environments. At constant soil-moisture conditions where no abrupt deviations are noticed, seed germination $(\%)$ increases with increasing temperature above base temperature and later on decreases at a higher temperature.

\section{Response of pulses low temperature/ cold stress}

Temperature lower than optimal growth temperature requirement causes low temperature or chilling stress. Stress due to temperature less than $15{ }^{\circ} \mathrm{C}$ is known as chilling stress and this occurs in plants which grow at $25-35^{\circ} \mathrm{C}$. In majority of pulse crops, chilling stress is noticed which occurs at temperature less than $10{ }^{\circ} \mathrm{C}$ but above $0^{\circ} \mathrm{C}$. Chilling stress is most commonly observed in sub-tropical and tropical species, such as pigeonpea and beans. Cool/ winter season pulses are highly sensitive to low temperature stress during flowering stage and early podformation phase. Kumar et al., (2016) reported average temperature range of $0-10^{\circ} \mathrm{C}$ to be considered as threshold level for cold stress in cool season crops. Cooler temperature coupled with wetter conditions leads to increased incidence of Ascochyta blight in chickpea, lentil and pea, Anthracnose in chickpea and lentil (Pande and Sharma, 2010). Chilling causes more loss in areas where growing season is short or crop is of long duration. In north India, we experience frost during November, December and January. Pulse crops sensitive to frost are chickpea, lentil, peas and long- duration pigeon pea. At freezing temperature, the photosynthesis is completely inhibited due to low temperature, moisture stress, internal injury, and production of ROS.

\section{Response of pulses salinity/ alkalinity stress}

The arable land is continuously transforming into saline soils globally and up to $50 \%$ land loss by salinity is predicted by 2050 (Hasanuzzaman et al., 2013). India has 6.74 million ha area under salt-affected soils, of 
which saline soils cover 1.71 million ha, alkali soils 3.79 million ha and costal saline soils 1.25 million ha. Area under pulse crops is declining gradually due to salinity stress, especially in Indo-Gangetic Plains of India. The reduction in the chickpea area in the traditional chickpea-growing regions is to a certain extent due to increased soil salinity and only availability of brackish water for irrigation (Gowda et al., 2009). Pulses are more sensitive to salinity than cereals and oilseeds. This could be due to accumulation of excess salts that quickens anthocyanin pigmentation in leaves and stems which reduces germination and seedling establishment of pulses (Kumar et al., 2016). Hence the pulse growth and development would be hindered due to salinity-induced moisture stress. Generously proportioned adverse effect is observed on the reproductive growth phase due to reduced partitioning of metabolites leading to a soaring loss in seed yield. Salt stress along with other pests attack (stem- and pod-borer) and yellow mosaic caused 80-100\% yield loss in mung bean, mostly during the rainy season due to salinityinduced desiccation, flower shedding and pod shattering (Sehrawat et al., 2015).

\section{Management strategies to cope up with abiotic stress in pulses}

In order to get better and sustain the pulse productivity at desired levels with respect to Indian perception for managing the abiotic stress, the development and enhancement of low-cost pulse production technologies need greater importance so that these technologies are good enough to resource-constrained Indian farmers. The most potential recent technologies in pulse production include superior crop establishment and management practices, merging and coordinating soil fertility and pest management actions, etc. which augment not only the productivity and profitability but also defend environmental and social sustainability besides nutritional security. A brief insight into status and production abilities of various improved crop management practices for managing the abiotic stress has been vividly presented below.

\section{Selection of suitable varieties/cultivars}

Varietal improvement programme in pulses was initiated in 1917 with selections from different parts of the country especially pigeonpea. Today, a great number of improved varieties have been tested and released for improved yield, drought resistance, salinity resistance, heat/cold resistance etc. suitable to varied agro-climatic and soil conditions. Thus, in particular, improvement of short duration cultivars, disease resistant and high yielding varieties resistant to certain abiotic stresses in the recent past made these crops a viable choice to low yielding coarse cereals under rain fed conditions and also provided a prospect for expansion in rice fallows and in double cropping systems. Breeding work is also underway to produce varieties and hybrids for almost all pulse growing areas throughout country for managing the heat, cold, salinity stresses (Table 3).

\section{Planting time and sowing depth}

Time of sowing is the most important nonmonetary input having significant effect on crop growth, phonological development, insect-pest and weed dynamics and crop productivity. Delayed planting restricts vegetative growth and pod bearing branches, decreases biological-nitrogen fixation and also leads to forced maturity. Rabi greengram can be sown up to end of December and this is practiced in southern part of country, where the winters are not severe. Sowing of summer greengram in first fortnight of March recorded higher yield as compared to last 
week of March (Patel 2003). Suitable time for summer blackgram is March (Jaiswal 1995) and for spring season January is the best month to obtain higher productivity (Reddy et al., 2007). September first week is the suitable time for horsegram sowing during rabi season (Kalita et al., 2003). Optimum sowing depth depends on type of crop/cultivar, growing season, soil moisture, soil texture, and more importantly on seed size of the respective pulse crops (Dass et al., 1997).

\section{Tillage methods}

In kharif pulses, raised/ridge-furrow planting technique has been found very successful in draining excess water from crop root zone and increase the yield by $25-30 \%$ over flat bed planting (Pramanik and Singh 2008, Das et al. 2014). Ali et al. (1998) observed that in Ludhiana (Punjab), flat sowing recorded significantly higher pigeonpea yield over other treatments, but at Hisar and Pantnagar in North Indian conditions, raised bed with $2.7 \mathrm{~m}$ width recorded significantly higher yield over other sowing methods. It might be due to proper drainage of excess water from crop root zone. Recommendation have been made to raise pulse crops under no - till practices for various benefits like utilizing moisture from undisturbed soil profile at sowing, reducing cost of productivity and better yields (Kang et al., 2007).

\section{Cereals (Rice and Wheat) response to temperature stress}

The rice-wheat cropping system is largely practised and is backbone of India's food security for century centuries. Rice (Oryza sativa L.) and wheat (Triticum aestivum L.) grown sequentially in rotation annually constitute a rice-wheat cropping system and is one of the world's largest agricultural production system not seen anywhere. India is world's second biggest rice and wheat producer. India contributes $26 \%$ in world rice production and $34.5 \%$ in world wheat production. Crop development, performance and yield depend largely on environmental interaction in this region. Knowledge about environment and crop interaction on growth, development and yield is of great importance. More the deviation from optimum temperature, growing degree days has a detrimental effect on crop growth, development and economic yield. Growth, development and productivity of wheat is unfavorably affected by the abiotic stresses like high temperature, low moisture regimes and nutrient stress To adapt to climate change, one need to understand the rising temperatures and tolerance level of plants. As stated in report by Inter-governmental panel on climate change, the global temperature will rise by $0.2^{0} \mathrm{C}$ per decade in the coming years. In wheat due to this condition of increasing temperature the maturity of the crop comes earlier (hastened) because the growing degree day requirement for maturity of wheat are met in short period. Plants detect changes in ambient temperatures through disturbance in metabolism, membrane fluidity, protein structure disintegration (Ruelland and Zachowski 2010). Heat stress is the function of rate, magnitude time and duration of exposure to the high temperature (Wahid et al., 2007).

\section{Rice: Temperature stress and management strategies}

Rice is indigenous to the humid areas of the tropical and subtropical regions and has wide adaptability (0-3000 $\mathrm{m}$ above mean sea level). It can be grown as transplanted or directly sown crop during the first crop season, depending on the availability of water, if other environmental conditions in the humid tropics are non-limiting. It is warmth loving crop requiring high temperature, ample water supply and high humidity during the growth period. 
Temperature is the most important cause which influences the growth, yield and development of rice. Being tropical and subtropical plant, rice generally requires high temperature above $20{ }^{\circ} \mathrm{C}$ but not above $35^{\circ}$ $40^{\circ} \mathrm{C}$. The crop duration varies with maximum temperature. The range of temperature from $21^{\circ}-37.5{ }^{\circ} \mathrm{C}$ is required throughout the life period of this crop. But, temperature range of $17^{\circ}-27.6{ }^{\circ} \mathrm{C}$ is ideal for the growth of rice plant. The optimum temperature range at flowering stage should be $26.5^{\circ}$ to $29.5^{\circ} \mathrm{C}$ and at ripening stage $20^{\circ}$ $25^{\circ} \mathrm{C}$ (Lenka 2006). The higher spikelet sterility in rice is noticed when crop is transplanted early in May and prevailing temperature is high at that stage (Chahal et al., 2007).

Rice grows best in dry and hot humid climate. Rice is sensitive to high temperature stress at flowering stage and maturity. Heat stress causes sterility during the reproductive stages. Due to climate change, temperatures are rising and reducing yields of rice.

According to Farrell et al., (2006) the flowering stage (anthesis and fertilization phenological stages) and to a lesser extent booting stage in rice crop are most susceptible stages of development to high temperature stress. A study at China and reported that high temperature induced sterility at anthesis in rice crop were characterized by its organspecific, high severity and low predictability of occurrence. Low temperature or cold stress is another major issue and constraints of rice production and productivity in temperate ricegrowing countries and high-altitude growing areas in the tropics. Cold stress cause seedling mortality and spikelet sterility and, eventually causes great and significant yield losses (Shimono et al., 2002). Anthesis to fertilization stage that involve anther dehiscence, pollen Germination and tube growth are temperature sensitive processes.
Heat stress during flowering results in spikelet sterility in rice due to decrease in the capability of pollen grains to swell resulting in poor dehiscence. Viability of pollen is lost if exposed to very high temperatures after some minutes. It was experimentally proven that in rice (Oryza sativa) sterility is induced within an hour if the crop is exposed to high temperature (Jagadish et al., 2007). Some genes might be repressed at elevated temperature. High temperature affects nearly all the metabolic processes of the plant which ultimately reflect in the form of reduction in rice crop yield and this is generally higher for susceptible genotypes compared to tolerant. Peng et al. (2004) noted a decline of $10 \%$ in grain yield of rice for every $1^{\circ} \mathrm{C}$ increase in minimum temperature during dry season.

Plants can tolerate the heat stress by various mechanisms like physiological, morphological and anatomical. Compatible solutes increase the plant's ability to retain water for transpirational needs and photosynthesis. Other mechanisms like decreasing cell size, closing stomata and more number of xylem vessels are also there. Plants metabolic system may also increase the production of stress proteins like catalase (CAT), superoxide dismutase (SOD), and peroxidase (POD). The plants have several mechanisms to cope with low temperature stress (Steponkus et al., 1993) and it appears that multiple mechanisms are triggered in this stabilization. The best documented are changes in lipid composition and the accumulation of sucrose and other simple sugars that typically occurs to protect cellular membranes.

According to Wahid( 2007), foliar application and pre-soaking seed treatment and $\mathrm{H}_{2} \mathrm{O}_{2}$ are good approaches.

Hardening of seeds by pre-soaking helped in tolerance to overheating and dehydration losses (Tikhomirova 1985). 
Kolupaev et al., (2005) concluded that exogenous application of $\mathrm{Ca}_{2}+$ endorse plant's heat tolerance. Application in the form of $\mathrm{CaCl}_{2}$ before the stress treatment has shown to increase the malondialdehyde (MDA) content (lipid peroxidation product), and stirred the activities of guaiacol peroxidase, SOD and catalase, which could be the reasons for the induction of heat tolerance.

\section{Wheat: Temperature stress and management strategies}

Wheat is a photo-insensitive and thermosensitive long day plant. Wheat requires cool climate during the early part of its growth. Temperature plays dominant role to wheat adaptation in India. Both the start and end of wheat crop season are limited by the onset and end of favorable temperature regimes. Within the growing season itself, warmer temperature shortens the vegetative crop duration. Phenological, morphological, physiological and biochemical traits of the wheat crop are affected by high temperature (HT) and ultimately decreases the crop yield. High temperature stress reduces the chlorophyll content and the photosynthetic competence of leaves. Heat stress is a complex physiological phenomenon and depends upon intensity (temperature in degrees), rate of increase in temperature and duration. Terminal heat stress results due to sudden rise in temperature following anthesis and continual stress is experienced when the mean daily temperature exceeds $17.5^{\circ} \mathrm{C}$ in the coldest month of the season.

As the temperature is increasing, ethylene production is also increasing which is due to increased ROS production and it resulted in shortening the length of grain filling period, decreased 1000-grain weight and advanced maturity (Beltrano et al., 1999). Terminal or late heat stress during the grain filling period of the normal or late sown wheat is considered as one of the major environmental factors severely dipping production in most of the areas. Prevailing climatic conditions are changing and temperature has begin to shoot up and rise in February and unfortunately sometimes with hot and dry winds at the postanthesis stages (grain development), terminating grain growth prematurely and reducing the wheat yield significantly. Drastic reduction in yield of wheat has been recorded with the delay of sowing beyond optimum time. Delay in wheat sowing 20 and 40 days from the normal sowing date $\left(15^{\text {th }}\right.$ November $)$ reduced grain yield by $23 \mathrm{~kg} / \mathrm{ha} /$ day and 30 $\mathrm{kg} / \mathrm{ha} /$ day, respectively (Kaur and Pannu 2008). The high temperature stress at reproductive phase of crop results in poor yield due to reduced number of grains per spike and shriveled grain with poor quality (Sharma et $a l ., 2007)$. The grain and straw yields of wheat were significantly affected due to its seeding time. Delay in seeding beyond timely seeding reduced the grain yield by 16.2, 37.4 and 39.9 per cent under moderately late, late and very late sown conditions respectively (Verma et al., 1997). According to Mohammadi (2011), heat stress is a most influential factor causing stress and limiting the wheat productivity in most of the growing areas of the world. The effect of this shock was observed in reduced grain filling duration, head weight of the inbred lines of wheat and kernel weight but did not influenced the kernel number. Some of the temperature stress management strategies in wheat crop are listed below.

Under these changing climatic conditions, aim should be towards the breeding of new crop varieties.

Genes from tolerant varieties should be incorporated into susceptible ones.

Agronomic management techniques includes water management strategies. Water application during heat stress helped in relieving the adverse effects of stress.(Dupont 
et al., 2006). Under moderate heat stress, nitrogen, phosphorus and potassium can improve plant growth. The same application of these fertilizers at post anthesis stage of growth can enhance more protein accumulation in the grain at day/night temperatures of $24 / 17{ }^{\circ} \mathrm{C}$ and not at $37 / 28^{\circ} \mathrm{C}$. (Dupont et al., 2006). Zinc helps in increasing the plant tolerance to high temperature in wheat(Graham and McDonald 2001).

Exogenous applications of chemicals in the form of osmoprotectants have been found effective in mitigating high temperature stress-induced damage in plants (Hasanuzzaman et al., 2011). Various osmoprotectants in use are proline, glycine betaine, trehaloseetc and phytohormones (abscisic acid, gibberellic acids, jasmonic acids, brassinosterioids, salicylic acid etc.).

Other giving positive effect are signaling molecules (nitric oxide), polyamines (putrescine, spermidine and spermine), trace elements (selenium, silicon etc.) and nutrients (nitrogen, phosphorus, potassium,calcium etc.)

Salicylic acid (SA) induced the increase in resistance of wheat seedlings injurious effect of high temperature on plant growth and may increase protein levels in plants (Senaratna et al., 2000) and (Apostolova et al., 2008).

Calcium may be help in signal transduction involving new gene manifestations under oxidative and temperature stress (Trofimova et al., 1999). Others (Mansfield et al., 1990 and Webb et al., 1996) reported that calcium control guard cell turgor and stomatal aperture.

\section{Water stress (Drought)}

Water is one the important factor for agricultural crops. Deficiency of water greatly reduces the yield (Wang et al., 2012). Many physiological processes in plants are impaired by drought stress, including photosynthesis, enzyme activity, membrane stability, pollen viability and ultimately growth (Flexas et al., 2004 and Valentovic et al., 2006). Drought is a chief cause of yield and quality failure in cereal crops throughout the world's cereal growing area, as well as developed countries (Akanda 2010, Bagci et al., 2007, Passioura 2007 and Sheng and Xiuling 2004).

Drought is threatning the world's largest area of agriculture (Tuberosa and Salvi 2006; Cattivelli et al. 2008) and worldwide research is going on to handle the drought stress. In order to meet the rising demands of developed nations like Africa and Asia, 60 per cent increase in food production worldwide is needed.

\section{Plant drought resistance and response}

Drought resistance can be successfully met by avoiding or tolerating the stress. In avoidance of drought, plants decrease the leaf area and increase the canopy resistance, closing of stomata and formation of root hairs (Beard and Sifers 1997; Rivero et al., 2007) and mechanisms of tolerance are at cellular and metabolic level. Resistance and tolerance e mechanisms are primarily focus turgor protoplasmic resistance, maintenance and dormancy (Beard and Sifers 1997). Under water stress conditions, plants modify their biochemical pathways through alterations of genes. But the exact mechanisms are still to be discovered.

Drought stress is often accompanied by other environmental stress factors, including temperature, high solar radiation and wind. Water and nutrition are two of the major components of environmental variations and together limits successful crop production. Mineral nutrients are essential for plant growth and development through their fundamental roles in plant metabolism, while 
drought is prominent among the most important ecological factors that impact crop growth and productivity (Bagci et al., 2007 and Passioura 2007).Zinc, B and $\mathrm{Mn}$ are involved in a wide range of physiological process within the plant cell, and several of these are also associated with tolerance to drought stress. These nutrients also play a key role in the maintenance of photosynthetic activity (Brown et al., 1993 and Karim et al., 2012a), pollen viability (Karim et al., 2012a and Sharma et al., 1990), the preservation of membrane integrity (Cakmak and Marschner1988a) and the continuance of enzyme activity (Cakmak and Marschner 1988b), as well as being an important factor in a plant's defense against reactive oxygen species, which proliferate under various stress conditions, including drought stress (Cakmak 2000). Several reports have confirmed that proline and abscisic acid (ABA) accumulation in plants can improve tolerance to drought stresses (De Ronde et al., 2004 and HmidaSayari et al., 2005).

\section{Effect and drought stress management strategies in rice crop}

Rice being a staple food crop is meeting the nutritional demands of three billion people for calorie intake (Khush 2005). Drought is affecting 23 million hectare of rainfed rice (Serraj et al., 2011). High temperature increases the evapo-transpirational demands of the crop and this also causes water stress under low rainfall areas.

Drought now is well recognized as an environmental disaster that impairs rice production. Much emphasis is given to drought tolerance improvement in rice and is one of the challenging tasks due to its complex and unpredictable nature.

Go for selection mechanisms for new varieties tolerant to water scarcity conditions.
Morphological mechanisms (leaf curling maintenance of turgor, deep and course roots) may be taken as strategy for tolerating moisture stress.

Leaf rolling helped in decreasing transpirational losses by reducing the surface area of leaves (Kadioglu and Terzi 2007). Internal water content of the plant is maintained due to this trait (Turner et al., 1986, Abd Allah 2009, Gana 2011 and Ha 2014). More leaf rolling also decreases the rate of photosynthesis which is a limitation.

Metabolic and physiological processes affected by water deficits include stomatal regulation, photosynthesis translocation, PSII activity, chlorophyll content, etc. Maintenance of these processes for desired period of time under moisture stress is a desired character.

ABA is also an important component of signalling under drought stress and efficient ABA signalling also ensures tolerance. Proline and polyamine helps in drought tolerance. So, these may be used as strategy for drought tolerance.

Agronomic management practices like bed planting has been found successful technology for water saving. This technology improves water distribution and efficiency, fertilizer use efficiency, reduced crop lodging and reduced seed rate without sacrificing yield (Hobbs et al., 2000). The farmers' participatory investigation done so far has shown the promise of this technology both in respect of productivity and water saving (Kamboj et al., 2008).

\section{Effect and drought stress management strategies in wheat crop}

Improvement in the productivity of wheat has played a key role in making the India selfsufficient in food grain production. However, general slowdown in increase in the output has 
been noticed particularly under quite favorable growing areas for its growth and development (Nagarajan 2005). Although wheat can be grown in a wide range of climatic conditions but many abiotic factors limit its yield. Limiting water resources under changing climatic conditions are posing a major threat to crop and water productivity. Increasing concern over the effect of climate changeon water resources requires that water should be used more efficiently in agriculture toincrease and sustain the productivity.

The water stress causes death of the different florets of the spike. Carbon and nitrogen availability for different growth stages is critical for certain stages such as heading stage of wheat and development but it affects the water stress by utmost (Oosterhuis and Cartwright 1983).

Two stages between stem elongation and milking stages is sensitive to water stress particularly in Asian countries (Li 1990). In the United States the most affected part of wheat which is affected was in between two stages such as from booting to soft-dough stage (Hanks and Rasmussen 1982). Recognizing the transient demand between these two plant growth stages have a particular high demand for micronutrients (Agarwal et al., 1981 and Sharma et al., 1990).

Different environments such as arid and rainfed conditions may present early water stress in the active growing season leading to less germination of wheat and crop establishment methods. Seed reserves are decreased leading to less germination of plants and higher mechanical impedance of soil may greatly reduce the crop establishment (Bouaziz and Hicks 1990).

The negative effects of early water stress are less likely if the bigger seeds of wheat are sown. The higher root biomass in newly grown seedlings from the bigger sized seeds may help to maintain a better water balance under early drought conditions and if moisture is available in lower layers in the soil profile (Mian and Nafziger1994). The active tillering stage is also sensitive to drought, being almost half the biomass as compare to conditions when not in stress. Therefore leaf area index stage is the most affected stage during whole development of plant. Water stress just before flowering or reproductive stages may also leads to decrease the number of spikelet primordial (Peterson et al., 1984 and Rickman et al., 1983). Lonbani and Arzani (2011) reported that the under the water stress the length increases but width is not affected at all however the overall leaf weight is also not affected. Leaf extension can also be limited under drought to get a better absorption of water by roots and ultimately the water conditions of plant tissues.

Drought can cut both yield and quality of crop (Bagci et al., 2007 and Kamara et al., 2003). Therefore any drought tolerant means would be welcomed in the continuing efforts to meet the challenge of worldwide water deficits in crop production.

In drought supervision technology increasing the biological and seed yield and different methods of crop establishment and highest rate of crop growth are considered. For improving the output in drought area, certain steps are indispensable such as incidence of water stress in the certain environment and matching with the phenology of crop (growth periods of crop, flowering, and seed filling) matching with the critical stages of soil moisture in a particular climatic zones, therefore developing the new means for better utilization of irrigation and increasing the status of soil water with certain management practices.

There are many field management practices to control water stress conditions such as 
irrigation methods (furrow, surface, drip and sprinkled) and identification of water stress resistance sources such as developing methods through screening. The repetition of experiments is important, but agronomic strategies such as sprinkler irrigation system, water harvesting shelters and evaluating of drought susceptibility index (DSI) is of utmost important (Schneekloth et al., 2012). Todd et al., (1991) reported that residue of wheat were reduced with the evaporation rate during the growing season and also slows movement of water all the way through the soil profile and gives more time for the water to infiltrate into the profile. Crop rotation can save the total water needs by irrigation. During the winter season growing wheat lowers the irrigation requirements. Schneekloth et al., (1991) reported that crop which is irrigated with 6 inches, leads to sowing of maize followed by wheat produced $8 \%$ higher maize yield than following the maize in rotation. Crop rotation with irrigation facilities lead to take higher time than solo crop. Breeding the crops for water resistance, productions of higher biomass and water use efficiency (WUE) are innovative strategies of Agronomy (Blum 1993). Scientists interest is rising in improving WUE of plant genotypes so that plants can expand and stand better under drought condition (Boyer 1996 and Ehdaie 1995).

Furthermore, during the breeding strategies the type of stress is more important than the target environment. The stagnation of yield during the water stress conditions and higher crop water productivity should be the topmost priority. The several studies reported through the genotypic variation in water stress tolerance have revealed several criteria associated with water stress, including maintenance of photosynthetic apparatus activity, improved cell membrane activity and stability leads to maintenance of enzymes' activity under water stress conditions. Early maturity, small plant size, short stature of plant and lower leaf area can be related to water stress tolerance (Rizza et al., 2004). Understanding the response of plant to water stress at all stages of plant's life is very vital point to progress in plant genetic engineering and breeding (Shi et al., 2010).

Coincidentally or otherwise, $\mathrm{Zn}, \mathrm{B}$ and $\mathrm{Mn}$ are also involved in maintaining photosynthetic activity (including maintaining the activity of drought sensitive enzymes), and preserving membrane integrity. The independent effects of $\mathrm{Mn}, \mathrm{B}$ and $\mathrm{Zn}$ may have a role in alleviating the damaging effects of drought on crop plants. Boron, Zinc and Mn applications raise the resistance of plants to drought stress (Azza et al., 2006, Khan et al., 2004, Movahhedy- Dehnavy et al., 2009 and Wei et al., 2005).Field observation of barley has indicated that adequate $\mathrm{Zn}$ nutrition can increase drought tolerance (King 1994), while decrease in grain yield due to drought stress in wheat was shown to be more marked when plants were $\mathrm{Zn}$ deficient (Bagci et al., 2007 and Ekiz et al., 1998).It has been established that micronutrients could prevent the suppression of leaf elongation under drought and finally the shoot dry matter production (Fukai et al., 1999, Pant et al., 1998 and Peleg et al., 2008).

\section{Effect and drought stress management strategies in Maize crop}

Maize productivity in the developed countries of North America and some part of Europe is nearly 8.7 ton/ha and 3.7 ton/ha as compared any agriculturally developed country in Asias (FAOSTAT 2012). Climatic conditions or water availability which may leads to drought and water logging, repectively is most important abiotic factor which destabilizing the yield of maize production. 
Table.1 Important abiotic stresses limiting productivity of major pulse crops in India

\begin{tabular}{|l|l|l|}
\hline Pulse Crop & Season & Abiotic stress \\
\hline \multirow{4}{*}{ Chickpea } & Timely sown & Low temperature, nutrient stress \\
\cline { 2 - 3 } & Early sown & Terminal drought, salt stress \\
\cline { 2 - 3 } & Late sown & Terminal drought, cold, nutrient stress \\
\hline \multirow{3}{*}{ Pigeonpea } & Kharif-early & Waterlogging, nutrient stress \\
\cline { 2 - 3 } & Medium late & Cold, terminal drought, waterlogging \\
\cline { 2 - 3 } & Pre-rabi & Cold, terminal drought \\
\hline \multirow{3}{*}{ Urdbean } & Kharif & Pre-harvest sprouting, terminal drought \\
\cline { 2 - 3 } & Zaid & Pre-harvest sprouting, temperature, drought stress \\
\cline { 2 - 3 } & Rabi & Terminal drought \\
\hline Lentil & Kharif & Terminal drought \\
\cline { 2 - 3 } & Zaid & Pre-harvest sprouting, temperature, drought \\
\cline { 2 - 3 } & Rabi/rice fallow & Terminal drought \\
\hline Clusterbean & ---- & Moisture, temperature \\
\hline \multirow{2}{*}{ Sistress } & --- & Moisture and nutrient stres \\
\hline
\end{tabular}

Source: Reddy (2006)

Table.2 Yield loss in major pulses due to abiotic stresses

\begin{tabular}{|l|l|l|}
\hline Crop & Abiotic stress & Yield loss (\%) \\
\hline \multirow{4}{*}{ Chickpea } & Terminal drought & $30-60$ \\
\cline { 2 - 3 } & $p$ H less than 6.0 & $22-50$ \\
\cline { 2 - 3 } & Salinity (ESP $>10)$ & Up to 50 \\
\hline \multirow{3}{*}{ Lentil } & Terminal drought & $6-54$ \\
\cline { 2 - 3 } & Salinity (ESP $>15)$ & Up to 50 \\
\cline { 2 - 3 } & $p$ H less than 6.0 & $30-86$ \\
\hline Faba bean & Terminal drought & Up to 70 \\
\hline Field pea & Terminal drought & $21-54$ \\
\hline
\end{tabular}

Source: Kumar et al. (2016)

Table.3 Selection of suitable varieties/cultivars

\begin{tabular}{|l|l|l|}
\hline Pulses & Variety & Resistance to abiotic stress \\
\hline \multirow{3}{*}{ Chickpea (Cicer arietinum) } & Karnal chana 1 & Resistant to salinity \\
\cline { 2 - 3 } & Phule G 95418 & Resistant to wilt \\
\cline { 2 - 3 } & Pusa 1088 & Large -seeded and moisture stresstoleran \\
\hline \multirow{2}{*}{ Cowpea (Vigna unguiculata) } & Gujrat Cowpea 2 & Drought tolerant \\
\cline { 2 - 3 } & UPC 9202 & Shattering tolerant \\
\hline \multirow{2}{*}{ Mothbean (Phaseolus aconitifolia) } & CAZRI Moth 1 & Drought resistant \\
\cline { 2 - 3 } & Jawala & Suitable for western part of India \\
\hline \multirow{2}{*}{ Redgram (Cajanus cajan) } & UPAS 120 & Very early, suitable for double cropping, escapes drought \\
\cline { 2 - 3 } & PPH 4 & Short duration, escapes drought \\
\hline Field pea (Pisum sativum) & Pusa Prabhat & Extra early maturity \\
\hline Frenchbean (Phaseolus vulgaris) & IPR 98-5 (Utkarsh) & Cold tolerance, attractive seed colour \\
\hline
\end{tabular}

Source: Prasad (2012), Bana et al., (2014) 
Occurrence of drought at early stage leads to higher root growth and adaptation that can tide over and manage the drought stress conditions. The meristem of the primary root of maize is effected badly by the drought stress which mau cause the meristemtic cells to become long and cell division is reduced along with the unit length increase of tissues and cell length in the meristem. Due to this reason the growth of the seedlings is blocked due to termination of the elongation of cell (Sacks et al., 1997, Anjum et al., 2003, Bhatt and Rao 2005).

The underground portion also affected by the deficit in water stress conditions, as root weight is increased while the shoot decreased with the deficit in water stress conditions (Morizet et al., 1983). At this situation the fresh and dry shoot and root weight is reduced to the extent of 40 and 58 percent respectively. The same conditions in maize can effect length and fresh weight of shoot due to affects by the water deficit condition prevailing in maize crop (Thakur and Rai, 1984).

In green house conditions the effect of drought stress on root and shoot growth of maize plant was reported that both the root and shoot growth were effected drastically by the water deficit conditions (Ramadan et al., 1985). Under restrictive availability of moisture the root shoot ratio was increased due to reason that roots are less vulnerable to water stress conditions than the shoot $(\mathrm{Wu}$ and Cosgrove 2000).

The series of development processes firstly growth, organ development then reproductive development such as flower production and grain filling are disturbed by the water deficit conditions. As the water deficit conditions prevails the opening and closing of stomata is affected which resulted in more closing than opening of stomata which resulted in the water use efficiency is increased but photosynthetic phenomenon is decreased. The decrease in photosynthetic fixation of carbon activates the molecular oxygen to produce the reactive oxygen species (ROS) and this damages the chloroplast and cell membrane apparatus. Drought stress during the reproductive period particularly one week prior to silking and two weeks after the silking is mainly important because the abortion of reproductive organs such as ovules, kernels and ears may occur in the ongoing process (Uhart and Andrade 1995). The water deficit decreases the carbon availability and dry matter portioning to the reproductive part such as ear at the critical stages which ultimately determine the number of grains in the plant (Andrade et al., 2000). This being the fact that water deficit conditions during the reproductive stage of plant may effect to lower the demand of carbon by decreasing the size of sink which results in tillers to degenerate, flower dropping and pollen may die and ovule abortion (Blum 1996).

Westgate and Boyer (1986) reported that low potential during the pollen shedding does not affect or restricts the process of pollination. Due to non-availability of photosynthesis the development process of embryo is restricted. Drought stress one week prior to silking and after two weeks significantly reduced the grain yield (53\% of the non-drought stressed). Less supply of moisture conditions to plant during the vegetative stages may cause the drastic reduction of full leaf area and ultimately utilization of carbon during the whole growing period will be lesser (Nilson and Orcutt 1996). The various stages of maize plant are affected differently during the drought stress conditions but the flowering, silking, pollination and grain formation process are the most deficit sensitive stages. Widespread and long existing drought stress at flowering period leads to reduction in growth of ear and silk formation which results in expanding gap between the anthesis and 
silking period. The increased gap could be important because it is directly related to kernel set of the maize plant (Byrne et al., 1995). Bergamaschi et al., (2004) reported that during the 1998/99 when a water deficit conditions prevail for long period resulted into just $4808 \mathrm{~mm}$ rainfall produces only 4.8 t/ha of grain yield of maize. (Dai et al., 1990).

Stress of moisture leading to drought and its management in maize is a complex mechanism as various phenomenon's such as molecular, biochemical and physiological and are needed to be learned which affects growth and development phases of crop plants (Razmjoo et al., 2008).

The mechanism of water deficit conditions tolerance involves many processes such as physiological and biochemical and molecular. First of all they include enhancing the stomatal resistance by decreasing of water loss. Certain mechanisms such as development of deep rooting system leads to more uptake of water. Over production of osmoprotectants and higher deposition of osmolytes leads to cope up with drought stress. Detoxification of ROS, both by enzymatic and non-enzymatic pathways leads to sustainability of the plasma membrane, synthesis of aquaporins in the cells and signaling pathways to initiate the production of stress proteins are the special mechanisms to cope up with water deficit conditions and become drought tolerance (Farooq et al., 2008).

Recommended application of potassium can increase the yield of maize plant increasing thousand grain weight and shelling percentage over control. Similarly in another experiment conducted by Roy and Kumar, (1990) leads to concludes that uptake of potassium can be enhanced by the enhance uptake of it's and also increased the available potassium content in the soils. The field experiments at Egypt shows that by restricting the irrigation leads to reduction in yield but it can be overcome by the application of potassium (Abd El Hadi et al., 1997).

If crop population is severely improper, replanting maize crop is also an option with farmer's with a shorter duration cultivar but this entails additional cost.

Short crop duration contributes an important attribute of drought escape so earlier maturing genotypes are better adapted to environments where the period of favourable water supply is short and the risk of water stress is relatively high.

Planting date coupled with selection of appropriate genotypes facilitates drought escape by matching the crop growth cycle to rainfall and temperature patterns to minimize the chance of exposure to water deficit at drought susceptible stages.

Skip row sowing (with 1 row not planted between every 2 or 3 rows of sowing) has been proposed as a means of improving crop reliability by restricting water use early in the season and maintaining a reserve of water in the soil in the wide row space produced by the omitted row (Zhang et al., 2005).

\section{Cereals response to salinity}

Salinity is well thought-out as a major factor which is affecting crop production and sustainability in arid and semiarid regions, lowering the value and output of the affected land. About 20 per cent irrigated agricultural land is adversely affected by salinity. A majority of plant species which is cultivated across the globe, especially the horticultural and cereals are glycophytes. It means they are susceptible to higher doses of dissolved ions in the solution of rhizosphere i.e. more 3 
$\mathrm{dS} / \mathrm{m}$. Salt stress means increased levels of salinity induces the disorders and malfunction such as osmotic, ionic and also secondary disorders such as oxidative stresses. Severity of salt stress would depend upon the concentrations and the length of stress, the stages of stress and most important the environmental conditions that prevailing that moment Zhu (2002).

Low and moderate salinity levels induces the Osmotic stress which decreases the soil water potential and ultimately curtailing the water uptake causing the dehydration of cell (Ondrasek et al., 2009).

Increasing the levels of salinity may reduce the potential of soil water from -1 to -2.5 but in extreme conditions it may reduces up to -5 $\mathrm{MPa}$ (Flowers and Flowers 2005), however it's potential at field capacity is $0.033 \mathrm{MPa}$. Water and nutrient uptake in the root cells decreases as the osmotic pressure in the rhizosphere under saline conditions. The responses of plant to osmotic stresses are due to osmotic stresses and closure of stomata whet ether partially or fully, transpiration and carbon assimilation reduction, cell growth and development is decreased, lesser leaf area and chlorophyll content, increased the rate of defoliation and senescence and the mortality of the plant's organism (Shannon and Grieve 1999).

Decrease in growth and yield reduction in yield causes the major threat in the salinity prone areas of the globe (Ashraf 2009). Plant death or decrease in the productivity at the whole plant level can be observed as a effect of high salinity (Parida et al., 2004). The reduction in yield can be seen when $\mathrm{pH}$ of soil solution exceeds the particular threshold level such as 8.5 or the electrical conductivity value goes above the $4 \mathrm{dS} \mathrm{m}^{-1}$. Electrical conductivity more than threshold values reduced the crop yield so drastically such that cultivation of crops without the soil amendments is not possible (Sairam and Srivastava 2002). Growth can only be resumed when the stress is relieved. Half of the world's saline soil used for the production of cereals is overlain with low availability of plant available zinc. It is due to zinc complexation and competition with dissolved salts at higher pH (Ondrasek et al., 2009). Undoubtedly, Salinity causes mineral deficiency in humans worldwide whether directly or indirectly because the primary route to most of essential minerals into the human are plants. Salinity causes certain secondary effects such as oxidative stress due to overproduction of reactive oxygen such as, $\mathrm{O}_{2}, \mathrm{H}_{2} \mathrm{O}_{2}$ and $\mathrm{OH}$ and is harmful to the proteins, nucleic acids, biomembranes and enzymes (Gomez et al., 2004).there are presence of certain antioxidant systems which detoxify the reactive oxygen like superoxide dismutase (SOD), catalases, and peroxidises, etc.

The resistant or susceptible plant to salt stress have differences according to the presence or absence of anti-oxidant system as certain relatively salt-tolerant species have higher activities of certain antioxidative enzymes (Hernandez et al., 2001), on the other hand in salt-sensitive species (e.g. cowpea) $\mathrm{Na}^{+}$ causes a inhibitory effect (Hernandez et al., 1994). Salt stress also affects the fresh and dry weight of plant parts such as leaves, stems, tillers, fertile tillers and roots (Chartzoulakis and Klapaki 2000). High concentration of ions competes with the uptake and translocation of some other nutrients also. Increasingly higher concentration of certain ions, likes $\mathrm{Na}^{+}$and $\mathrm{Cl}^{-}$due to application of $\mathrm{NaCl}$ leads to lowering in concentration of other ions such as $\mathrm{Ca}^{2+}, \mathrm{Mg}^{2+}$ and $\mathrm{K}^{+}$in plants (Khan et al., 1999). Negative relationship occur between $\mathrm{Na}+$ and $\mathrm{K}+$ concentration in indifferent plant parts, particularly roots and leaves. 
Effect and management strategies to reduce impact of salinity in rice

Rice a salt-sensitive monocot (Darwish et al., 2009, Maas and Hoffman 1997 and Shereen et al., 2005) is the most abundantly gown cereals worldwide and salinity is the main constraint affecting the mineral nutrition (Marschner 1995). It is more sensitive to salinity during seedling, panicle initiation and flowering stages than other stages (Yoshida 1981, Zeng et al., 2001, Grattan et al, 2002). Salinity is becoming more prevalent as the intensity of agriculture increases in rice dominating cropping sequence and has become most crucial environmental factor. Around the world some 100 million ha or 5\% of arable land has been adversely affected by high salt concentrations reducing crop growth and yield (Ghassemi et al., 1995 and Gunes et al., 2007). Many reports had been concluded to prove salt induced reduction in photosynthetic pigments in rice (Cha-um et al., 2007). Plants show high chlorophyll degradation symptom, chlorosis, as a common morphological and physiological characteristic in response to salt stress (Harinasut et al., 2000) and according to Yeo and Flowers (1983) chlorophyll content of salt stressed rice can be described as a function of the leaf sodium content.

Salinity is most serious abiotic factor which reduces the production of rice anywhere. At present there are different strategies which helps in overcoming the salt stress and some of these are raising of tolerant cultivars to salt stress, water management strategies and dissimilar cultural practices. However, but none alone can mitigate exclusively and achieve desired results.

Quality parameters in rice can be initiated for improvement, being cultivated under unavoidable circumstances of salt effected areas. The use of brassinosteroids have been demonstrated in several research trials to prove the effects in increasing in yield and its different parameters in enduring enhancement of salt tolerance and in adaptation strategies against salt induced stress. Recent studies have shows the effect of brassinosteroids in mitigating the stress tolerance mechanism of crops making this a new avenues to solves the tribulations of salinity in rice (Oryza sativa L.) (Phap2006).

Application of Brassinosteroids can cover the inhibitory effect of salts on pigments and this explains the reason that why higher growth of plants supplied with brassinosteroids under saline stress conditions may continue to grow well. It plays an important role in osmoregulation and stability of membrane. Brassinosteroids plays an important role in osmoregulation and stability and also cause the chlorophyll content to shoots up in the leaves of crop plants such as wheat, rice, Brassica juncea and Vigna radiata (Rao et al., 2002). (Sairam 1994, Wang 1997, Farid uddin et al., 2003, Rao et al., 2002).

Tolerance of salt is linked to excluding the $\mathrm{Na}^{+}$ion and its translocation and sharing of similar concentration in all plant leaves (Ashraf and O'Leary 1995 and Haq et al., 2009).

Breeding efforts in India got remarkable improvement when the native land races of coastal Sunderban areas in west Bengal were used for the breeding purposes. These varieties were Damodar (CSR1), Dasal (CSR2) and Getu selected on the basis of identification, selection and introgression on the hypothesis of their tolerance to salt stress.

These varieties serves as the varieties selected for donor for salt tolerance for high yielding and semi-dwarf and early maturing varieties with better grain 
quality. These varieties were photosensitive and grown traditionally. There are several examples are present in the literature such as one of them is use of basmati variety CSR30 (Yamini) which is derived from the cross like BR410/Pakistan Bas.1 from coastal saline areas of Maharashtra.

\section{Effect and management strategies to reduce impact of salinity in wheat}

The data by the international institute CIMMYT about the cultivated areas of wheat in Asian and African countries like India, Pakistan, Mexico, Libya and Egypt suggest that 10 percent of cultivated areas of wheat is effected by salinity stress (Mujeeb - Kazi and Diaz de Leon, 2002). The water deficit arises from the salinity even though the conditions will be well watered leads to decreasing the osmotic potential of soil solutes thus making it difficult for rooting system to extract water from the surrounding media (Sairam et al., 2002). The ultimate terminating effect of high salinity on plant can be measured in terms of plant death and decrease in productivity (Parida et al., 2004).

Plant growth and crop productivity is affected by abnormal conditions and salinity is one of them. Over time it has become a one of the major factor which limits the yield potential (Allakhverdlev et al., (2000). The soils of worldwide are becoming more saline with each passing day by various reasons and from irrigation water, the unnecessary fertilization and desertification process. The strategies for alleviating the salt stress involves the cultivars which are salt tolerant, leaching of excess soluble salts to lower depths of soil, harvesting salt-accumulating aerial plant with insignificant irrigation and ameliorating the soils under cropping (Badlio et al., 2004).
Salinity affects the growth and plant development processes the ion cytotoxicity which ultimately alters the cytosolic ratio of sodium and potassium and results into osmotic tension.

This whole process disrupts the distribution process and cerrtain other homeostasis processes that lead to denaturation of the structural proteins (Serrano et al., 1999). There are presence of certain mechanism such as excluding the sodium ion at the plasma membrane or sequestration of sodium ions in the intercellular vacuoles and its accumulation of the different osmolites and different osmoproctentants (Serrano et al., 1999, Zimmermann and Sentenac 1999, Blumwald 2000). Through this system plants can maintain the ratio of potassium and sodium and optimum osmolarity of cell to maintain turgor.

Several approaches to improve and enhance the salt tolerance by evolving the genes for tolerance has been used into the different cultivars, screening of the large germplasm and large research trials of some cultivars, conventional breeding and through molecular approaches has been studied thoroughly to draw the strategies against the salinity tolerance (Munns, 2005 (Munir et al., 2011) (Shahzad et al., 2012), (Salam et al., 1999) (Colmer et al., 2006).

The alternative method to cope up with salt stress is through inoculation of crop seeds or seedlings with growth promoting bacteria (PGPB). Some studies have suggested favorable effects seen in hydraulic conductance, osmolyte accumulation, maintaining higher stomatal conductance and photosynthetic activities (Dodd and Perez 2012).

Appropriate traits for salt tolerance by exploiting the different screening methods can be utilized by different crop plants due to varietal differences (Colmer 
et al., 2006). Kharchia 65 in Pali district of Rajasthan were identified to possess salt tolerance to salinity and sodicity stresses. These land races proved to be the donors for improving the tolerance to salinity in wheat and played a significant role in wheat breeding efforts at Karnal.

Not only economic yield but agronomic parameters such as number of tiller, fertile tillers, 1000 grain weight have been used for the assessment of salt tolerance. Earlier grain yield was mostly used as the main criteria evaluating the the salt tolerance (Jafari-Shabestary et al., 1995).

\section{Effect and management strategies to reduce impact of salinity in maize}

Maize as dominant food crop grow in many arid regions has been classified as a moderately sensitive crop to salinity (Ouda et al., 2008). Adverse effect of salinity on crop is observed during germination and early growth stages (Carpici et al., 2009). Germination and optimal seedling growth are very important for better crop establishment. Decrease of germination rates and seedlings growth under high salinity condition was reported by Jamil et al., (2006) and Asaadi (2009). Some of the Management strategies to reduce impact of salinity in maize crop are listed below -

The application of growth regulators such as salicylic acid can improve plant growth and photosynthetic competence in saline conditions (Khan et al., 2012). Regulating the different plant growth regulating processes like stomata closing, uptake of ion, the biosynthetic process leads to ethylene accumulation, transpiration and photosynthesis under environment and conditions of salinity (Shakirova et al., 2003, Gunes et al., 2005, Waseem et al., 2006, Khan et al.,
2012). It has been authenticated that exogenous application of salicylic acid improves tolerance to stress by increasing antioxidant such as peroxidase (POD), superoxide dismutase (SOD) and catalase (CAT) activity (Noreen et al., 2009).

Silicon (Si) may be beneficial for the plant growth and photosynthetic activity. According to the literature and under the salt stress conditions, Si enhanced the $\mathrm{K}^{+} / \mathrm{Na}^{+}$ratio against the toxic effects of $\mathrm{Na}^{+}$. Sodium $\left(\mathrm{Na}^{+}\right)$transportation into roots and shoots as well as shoot $\mathrm{K}^{+}$and $\mathrm{Ca}^{+2}$ concentrations was reduced by added silicate. $\mathrm{Si}$ application reversed the chlorosis and protected the chloroplast from disorganization It increased the resistance of some plant species to toxic metals (Cadmium) and accumulations which damages chloroplast and root-to-shoot transport (Tuna et al., 2008 and Feng et al., 2010).

PGRs like GA3 can improve the plant growth, ion uptake and transport and the nutrient utilization under salt stress. They are crucially responsible and mandatory for seed germination, leaf expansion of leaf and flowering. They also prevent chlorophyll breakdown and decreases the ROS levels that lead to death of cells. They stabilize microtubules in plant organs against de-polymerization (Janda et al., 2012 and Bose et al., 2013).

In conclusion although a lot of research is in progress in the field of abiotic stress and heat stress in particular, but still the global food security is at stake due to the over exploding population and unpredictable climate change. Despite this fact of extensive and long studies, there is an urgent need for more detailed characterization of the studied response and management strategies for 
cereals (rice, wheat and maize) under drought, temperature and salinity stresses that is occurring in growing fields. Hence, it is necessary to develop genotypes that can yield reasonably under high temperature and reach out into the farmer's fields. Therefore it is essential to incorporate all the parameters of plant like crop physiology, agronomic strategies, molecular genetics approaches and different breeding objectives to dissect complex stress tolerance traits and develop the next generation crops which can withstands the adverse climate and successfully ensure food security to ever increasing world population.

\section{References}

Abd Allah A A (2009). Genetic studies on leaf rolling and some root traits under drought conditions in rice (Oryza sativa L.). Afr J Biotechnol8: 6241-48.

Abd El-Hadi A H, Ismail K M and El-Akahawy M A (1997) Effect of potassium on the drought resistance of crops in Egyptian conditions. In: Johnston, A. E. (eds.) Food Security in the WANA Region, the Essential Need for Balanced Fertilization. International Potash Institute, Basel, pp: 328-336.

Acquadh (2007) Principle of plant genetics and breeding. Willey Blackwell, Oxford.

Agarwal S C, Sharma P N, Chatterjee C and Sharma C P (1981) Development and enzymatic changes during pollen development in boron deficient maize plants. J Pl Nutr 3: 329-336.

Akanda A (2010) Rethinking crop diversification under changing climate, hydrology and food habit in Bangladesh. J Agri Environ Int Dev104:3-23.

Ali M, Mishra J P and Chauhan Y S (1998) Effective management of legume for maximizing biological $\mathrm{N}$ fixation and other benefits. (In) Residual effect of legume in rice and wheat cropping system in the IndoGangetic plains pp 127-8.

Allakhverdiev S I, Sakamoto A, Nishiyama Y, Inaba M, Murata N (2000). Ionic and osmotic effects of NaCl-induced inactivation of Photosystems I and II in Synechococcus sp. Pl Physio123:1047-56.

Andrade F.H., Cirilo A G Echarte L (2000) Factors affecting kernel number in maize. In "Physiological bases for maize improvement", pp. 59-74.

Anjum F M, Yaseen E, Rasul, Wahid S, Anjum (2003) Water stress in barley (Hordeum vulgare L.). I. Effect on morphological characters. Pak J Agric Sci40: 43-44.

Apostolova P, Yardnova R and Popova L (2008) Response of anti-oxidative defense system to low temperature stress in two wheat cultivar. Gen Appl Pl Physio 34: 281-94.

Asaadi A M (2009) Investigation of salinity stress on seed germination of Trigonellafoenumgraecum Res J Biol Sci4:1152-1155.

Ashraf M (2009) Biotechnological approach of improving plant salt toleranceusing antioxidants as markers. Biotech Adv 27: 84-93.

Ashraf M and O'Leary JW (1995) Distribution of cations in leaves of salt-tolerant and salt sensitive lines of sunflower under saline conditions. J Pl Nutr 18: 2379-88.

Azza A M, Mazher S, Zaghloul M (2006) Increasing water deficiency tolerance of Melia azedarach seedlings through application of iron. World J Agric Sci2: 346-351.

Badlio M, Rodriguez H, Moreno M, Hernandez JP and Bashan Y (2004) Mitigation of salt stress in wheat seedlings by a gfp-tagged Azospirillum lipoferum. Bio Fertil Soils40:188-93.

Bagci S A, Ekiz H, Yilmaz A and Cakmak I (2007) Effects of zinc deficiency and drought on grain yield of field grown wheat cultivars in Central Anatolia. J Agron Crop Sci193:198-206.

Bana R S, Pooniya V, Choudhary, A K and Rana K S (2014) Agronomic interventions for sustainability of major cropping systems of India. Technical Bulletin (ICN: 137/2014), Indian Agricultural Research Institute, New Delhi, India, pp. 34

Beard J B and Sifers S I (1997) Genetic diversity in dehydration avoidance and droutght resistance within the Cynodon and Zoysia species. Int Turf Soc Res J8: 603-610 
Beltrano J, Montaldi ER, Bartoli CG, Carbone A (1999) Emission of water stress ethylene in wheat (Triticum aestivum L.) ears: effects of rewatering. Pl Growth Regul21:121-126.

Bergamaschi H, Dalmago A G, Bergonci I J, Bianchi M A C, Muller G A, Comiran F and Heckler M M B, (2004) Water supply in the critical period of maize and the grain production. J Pesquisa Agropecuaria Brasileira39: 831-839.

Bhatt R M and Rao N K S (2005)Influence of pod load response of okra to water stress. Indian J Pl Physiol10: 54-59.

Blum A (1993) Selection for sustained production in water-deficit environments. Internat Crop Sci. I. Madison, Wisconsin: Crop Sci Soc Am 343-347.

Blumwald E (2000) Sodium transport and salt tolerance in plants. Curr Opin Cell Biol12:431-34

Bose S K, Yadav R K, Mishra S, Sangwan R S, Singh A K, Mishra B, Srivastava A K and Sangwan N S (2013) Effect of gibberellic acid and calliterpenone on plant growth attributes, trichomes, essential oil biosynthesis and pathway gene expression in differential manner in Mentha arvensis L. Plant Physiol Biochem66:150-158.

Bouaziz A and Hicks D R (1990) Consumption of wheat seed reserves during germination and early growth as affected by soil water potential. Pl Soil 128: 161-165.

Boyer J S (1996) Advances in drought tolerance in plants. Adv Agron56: 187-218.

Brown P H, Cakmak I, Zhang Q and Robson A D (1993) Form and function of zinc plants.

Byrne P F, Bolaños J, Edmeades G O and Eaton D L (1995) Gains from selection under drought versus multilocation testing in related tropical maize populations. Crop Science 35:63-69

Cakmak I (2000) Possible roles of zinc in protecting plant cells from damage by reactive oxygen species. New Phytol146:185-205.

Cakmak I and Marschner H (1988a) Increase in membrane permeability and exudation in roots of zinc deficient plants.J Pl Physiol 132: 356-361.

Cakmak I and Marschner H (1988b) Zincdependent changes in ESR signals, NADPH oxidase and plasma membrane permeability in cotton roots. Physiol Pl73: 182-186.

Carpici E B, Celik N and Bayram G (2009) Effects of salt stress on germination of some maize (Zea mays L.) cultivars. Afr J Biotechnol 8: 4918-22.

Cattivelli L, Rizza F, Badeck F W, Mazzucotelli E, Mastrangelo A M, Francia E, Marè C,Tondelli A and Stanca A M (2008) Drought tolerance improvement in crop plants:An integrated view from breeding to genomics. Field Crop Res105: 1-14.

Chahal G B S, Sood A, Jalota S K, Choudhury B U and Sharma P K (2007) Yield, evapotranspiration and water productivity of Rice-Wheat system in Punjab (India) as influenced by transplanting date of Rice and weather parameters. Agric Water Manage88: 14-22.

Chartzoulakis K and Klapaki G (2000) Response of two green-house pepper hybrids to $\mathrm{NaCl}$ salinity during different growth stages. Sci Hort86: 247-60.

Cha-um S, Supaibulwatana K and Kirdmanee C (2007) Glycinebetaine accumulation, physiological characterizations and growth efficiency in salt-tolerant and salt-sensitive lines of indica rice (Oryza sativa L. ssp. indica) in response to salt stress. J Agron Crop Sci193: 157-66.

Colmer T D, Flowers T J and Munns R (2006) Use of wild relatives to improve salt tolerance in wheat. J Exp Botany 57:10591078.

Dai J Y, Gu W L, Shen X Y, Zheng B, Qi H and Cai S F (1990) Effect of drought on the development and yield of maize at different growth stages. J Shenyag Agric Univ21:181-85.

Darwish E, Testerink C, Khalil M, El-Shihy O and Munnik T (2009) Phospholipid signaling responses in salt-stressed rice leaves. Pl Cell Physio50: 986-97.

Das T K, Choudhary A K, Sepat S, Vyas A K, Das A, Bana R S and Pooniya V (2014) Conservation agriculture: A sustainable alternative to enhance agricultural productivity and resources-use efficiency. Technical Extension Folder, Indian Agricultural Research Institute, New Delhi, India 
Dass A, Kharwara P C and Rana S S (1997) Response of gram varieties to sowing dates and phosphorus level under on-farm conditions. Himachal Journal of Agricultural Research 23: 112-5.

Dass A, Suri V K, Choudhary A K. (2014) Sitespecific nutrient management approaches for enhanced nutrient-use efficiency in agricultural crops. Research and Reviews: Journal of Crop Science and Technology 3 (3): $1-6$.

De Ronde J A,Cress W A, Krüger G H J, Strasser R J and VanStaden J (2004) Photosynthetic response of transgenic soybean plants, containing an Arabidopsis P5CR gene,during heat and drought stress. J Pl Physio 1161: 1211-1224.

Dodd I C and Perez-Alfocea F (2012) Microbial alleviation of crop salinity. J Exp Bot63:3415-28.

Dupont F M, Hurkman W J, Vensel W H, Tanaka C, Kothari K M, Chung O K and Altenbach S B (2006) Protein accumulation and composition in wheat grains: effects of mineral nutrients and high temperature. Eur J Agron. 25: 96-107.

Ehdaie B (1995) Variation in water use efficiency and its components in wheat II. pot and field experiments. Crop Sci35: 1617-1629.

Ekiz H, Bagci S A, Kiral A S, Eker S, Gultekin I, Alkan A, Cakmak I (1998) Effects of zinc fertilization and irrigation on grain yield and zinc concentration of various cereals grown in zincdeficient calcareous soils. $\mathrm{J}$ Plant Nutr21: 2245-2256.

FAOSTAT (2012) http://faostat.fao.org (accessed 15 November, 2012).

Fariduddin Q, Ahmad A and Hayat S (2003) "Photosynthetic response of Vigna radiata to pre-sowing seed treatment with 28homobrassinolide."Photosynthetica"41: 307-10.

Farooq M, Basra S M A, Wahid A, Cheema Z A, Cheema M A and Khaliq A (2008) Physiological role of exogenously applied glycinebetaine in improving drought tolerance of fine grain aromatic rice (Oryza sativa L.). J Agron Crop Sci194: 325-33.

Farooq M, Wahid A, Kabayashi D, Fujita and Basra (2009) Plant drought stress: effects, mechanisms and management. (In)
Sustainable Agriculture, pp. 153-188.

Farrell T C, Fox K M, Willians R L and Fukai S (2006) Genotypic variation for cold tolerance during reproductive development in rice: screening with cold air and cold water. Field Crops Res 98:178-94.

Feng J, Shi Q, Wang X, Wei M, Yang F and Xu H (2010) Silicon supplementation ameliorated the inhibition of photosynthesis and nitrate metabolism by cadmium $(\mathrm{Cd})$ toxicity in Cucumis sativus L. Sci Horticult123: 521530.

Flexas J, Bota J, Loreto F, Cornic G, Sharkey TD (2004)Diffusive and metabolic limitations to photosynthesis under drought and salinity in $\mathrm{C}_{3}$ plant. Pl Bio6: 269-279.

Flowers T J and Flowers S A (2005) Why does salinity pose such a difficult problem for plant breeders. Agric Water Manag78:1524.

Fukai S, Pantuwan G, Jongdee B and Cooper M (1999) Screening for drought resistance in rainfed lowland rice. Field Crops Res64: 61-74.

Gana A S (2011) Screening and resistance of traditional and improved cultivars of rice to drought stress at Badeggi, Niger State, Nigeria. Agric Biol J North Am2: 1027-31.

Ghassemi F, Jakeman A J and Nix H A (1995) Global resource overview. In: Ghassemi F, Jakeman AJ and Nix HA, editors. Salinization of Land and Water Resources. Wallingford,Oxon UK: $\quad$ CAB International.pp 2-19.

Gomez J M, Jimenz A, Olmas E and Sevilla F (2004) Location and effects of long-term $\mathrm{NaCl}$ stress on superoxide dismutase and ascorbate peroxidase isoenzymes of pea (Pisum sativum cv. Puget) chloroplasts. J Exp Bot55: 119-30.

Gowda C L L, Rao P P, Tripathy S, Gaur P M and Deshmukh R B (2009) Regional shift in chickpea production in India.(In) Milestones in Food Legumes Research. Ali, Masood and Kumar, Shiv (Eds). Indian Institute of Pulses Research, Kanpur, Uttar Pradesh, India, pp. 21-35.

Graham A W and McDonald G K (2001) Effect of zinc on photosynthesis and yield of wheat under heat stress. In: Proceedings of the 10th AustralianAgronomy Conference 
Hobart, January 29-February 1, 2001, Australian Society of Agronomy, Hobart, Tasmania, Australia. Available at: http:/www.regional.org.au/au/asa/2001/2/c/ graham.htm.

Grattan S R, Zeng L, Shannon M C, Roberts S R (2002) Rice is more sensitive to salinity than previously thought. California Agric56: 189-195.

Gunes A, Inal A, Alpaslan M, Cicek N, Guneri E, Eraslan F and Guzelordu T (2005) Effects of exogenously applied salicylic acid on the induction of multiple stress tolerance and mineral nutrition in maize (Zea mays L.). Arch Agron Soil Sci51: 687-695.

Gunes A, Inal A, Alpaslan M, Eraslan F, Bagci E $G$ and Cicek N (2007) Salicylic acid induced changes on some physiological parameters symptomatic for oxidative stress and mineral nutrition in maize (Zea mays L.) grown under salinity. J Pl Physio164: 728-36.

Ha P T T (2014) Physiological responses of rice seedlings under drought stress. J Sci Devel12: 635-40.

Hanks R J and Rasmussen V P (1982) Predicting crop production as related to plant water. Adv Agron35: 193.

Haq T, Akhtar J, Nawaz S and Ahmad R (2009) Morpho-physiological response of rice (Oryza sativa L.) varieties to salinity stress. Pak J Bot41: 2943-56.

Harinasut P, Srisunak S, Pitukchaisopol S and Charoensataporn R (2000) Mechanisms of adaptation to increasing salinity of mulberry: proline content and ascorbate peroxidase activity in leaves of multiple shoots. Sci Asia26: 207-11.

Hasanuzzaman M, Hossain M A and Fujita M (2011) Nitric oxide modulates antioxidant defense and the methylglyoxal detoxification system and reduces salinityinduced damage of wheat seedlings. Pl Biotechnol Rep5: 353-65.

Hasanuzzaman M, Nathan K and Fujita M (2013) Plant response to salt stress and role of exogenous protectants to mitigate salt induced damages. (In) Ecophysiology and Responses of Plant under Salt Stress, pp.25-87, Springer, New York,

Hernandez J A Rio D L A and Sevilla F (1994)
Salt stress induced changes in superoxide dismutase isozymes in leaves and mesophyll protoplasts from Vigna unguiculata (L.) Walp. New Phytol126: 3744.

Hernandez J A, Ferrer M A, Jimenez A, Barcelo A R and Sevilla F (2001) Antioxidant systems and $\mathrm{O}_{2}-/ \mathrm{H}_{2} \mathrm{O}_{2}$ production in the apoplast of pea leaves. Its relation with saltinduced necrotic lesions in minor veins. Pl Physio127: 817-31.

Hmida-Sayari A, Gargouri-Bouzid R, Bidani A, Jaoua L, Savouré A and Jaoua S (2005) Over expression of $\Delta 1$-pyrroline-5-carboxy late synthetase increases proline production and confers salt tolerance in transgenic potato plants. Pl Sci169: 746-752.

Hobbs P R, Singh G S and Duxbury J M (2000) Direct seeding and reduced tillage options in the rice-wheat systems of the IndoGangetic Plains of South Asia. In: Paper Presented at IRRI Workshop. Bangkok, Thailand pp 25-28.

Jafari-Shabestari, Corke J H and Qualset C Q (1995) Field evaluation of tolerance to salinity stress in Iranian hexaploid wheat landrace accessions. Genetics Res Crop42: 147-56.

Jagadish S V K, Craufurd P Q and Wheeler T R (2007) High temperature stress and spikelet fertility in rice (Oryza sativa L.) J Exp Botany 58:1627-1635.

Jaiswal V P (1995) Performance of greengram (Phaseolus radiatus) and blackgram (Phaseolus mungo) genotypes to dates of planting during summer. Indian $\mathbf{J}$ of Agronomy 40 (3):516-8.

Jamil M, Lee D B, Jung K Y, Ashraf M, Lee S C and Rha E S (2006) Effect of salt $(\mathrm{NaCl})$ stress on germination and early seedling growth of four vegetables species. J Cent Eur Agr7:273-82.

Janda K, Hideg E, Szalai G, Kovacs L and Janda $T$ (2012) Salicylic acid may indirectly influence the photosynthetic electron transport. J Pl Physiol169: 971-78.

Kadioglu A andTerzi R (2007) A dehydration avoidance mechanism: Leaf rolling. Bot Rev73: 290-302.

Kalita U, Suhrawardy J and Das J R (2003) Response of horsegram (Dolichos biflorus) 
to different seed rates and dates of sowing under rainfed upland situations. Crop Research 26 (3): 443-5.

Kamara A Y, Menkir A, Badu-Apraku B, Ibikunle O (2003) The influence of drought stress on growth, yield and yield components of selected maize genotypes. J Agric Sci141: 43-50.

Kamboj B R, Malik R K, Garg R, Yadav, Singh S, Goyal, Lathwal N K, Malik O P, Pal Y and Mehla O P (2008) Bed planting - A novel technique to encourage multiple land use. Tech Bulletin (29). Directorate of Extension Education, CCS Haryana Agricultural University, Hisar, India pp. 24.

Kang J S, S. S. Sandhu, Jagdish-Singh, HarmeetSingh, Harrajdeep Kang, Kamaljit Grewal, and Gurbir Singh 2015. Climate Change: Causes, Contributors And Its Impact On Crop Production. Int J Agric Sci 7 (8): 60105.

Karim M R, Zhang Y Q, Zhao R R, Chen X P, Zhang F S and Zou C Q (2012a) Alleviation of drought stress in winter wheat by late foliar application of zinc, boron, andmanganese. J Pl Nutr Soil Sci175:142151.

Kaur A and Pannu R K (2008) Effect of sowing time and nitrogen schedules on phenology, yield and thermal-use efficiency of wheat (Triticum aestivum). Indian J Agric Sci 78: 366-69.

Khan H R, McDonald G K, Rengel Z (2004) Zinc fertilization and water stress affects plant water relations, stomatal conductance and osmotic adjustment in chickpea (Cicer arientinum L.). Pl Soil 267: 271-284.

Khan M A, Ungar I A and Showalter A M (1999) Effects of salinity on growth, ion content and osmotic relations in Halopyrum mocoronatum L. J Pl Nut22: 191-204.

Khan S U, Bano A, Din J and Gurmani A R (2012) Abscisic acid and salicylic acid seed treatment as potent inducer of drought tolerance in wheat (Triticum aestivum L.). Pak J Bot44:43-49.

Khan W, Prithiviraj B and Smith. D L (2003) Photosynthetic responses of corn and soybean to foliar application of salicylates. J Pl Physiol160: 485-92.

Khush G S (2005) What it will take to feed 5.0 billion rice consumers in 2030. Pl Mol Bio59: 1-6.

King P (1994) Crop and seed nutrition. New Crop Sci Soc S Aust132:7-8.

Kolupaev Y, Akinina G and Mokrousov A (2005) Induction of heat tolerance in wheat coleoptiles by calcium ions and its relation to oxidative stress. Russ. J Plant Physiol52: 199-204.

Krishnamurthy L, Kashiwagi J, Gaur P M, Upadhyaya H D, Vadez V (2010) Sources of tolerance to terminal drought in the chickpea (Cicer arietinum L.) minicore germplasm. Field Crops Research 119: 322330.

Kumar K, Solanki S, Singh S N and Khan M A (2016) Abiotic constraints of pulse production in India. (In) Disease of Pulse Crops and their Sustainable Management, pp. 23-39, Biotech Books, New Delhi, India

Lenka D (2006) Climate, Weather and Crops in India. Pp 157. Kalyani Publisher, New Dehli.

Li H (1990) Analysis and study on crop sensitivity index and sensitivity coefficient. Irrig Drain9:7-14.

Lonbani M and Arzani A (2011) Morphophysiological traits associated with terminal drought stress tolerance in triticale and wheat. Agron Res9: 315- 329.

Lopez F B, Johansen C and Chauhan Y S (1996) Effects of timing of drought stress on phenology, yield and yield components of short duration pigeonpea. Journal of Agronomy and Crop Science 177: 311-320.

Maas E V and Hoffman G J (1997) Crop salt tolerance. Current assessment. ASCE J Irrig Drain Div103: 116-134.

Maheswari M, Sarkar B, Vanaja M, Srinivasarao M, Srinivasarao Ch, Venkateswarlu B and Sikka A K (2015) Climate resilient crop varieties for sustainable food production under aberrant weather conditions. Technical Bulletin, ICAR-Central Research Institute for Dryland Agriculture, Hyderabad, p. 47.

Mansfield T, Hetherington A M and Atkinson C J (1990) Some current aspects of stomatal physiology. Annu Rev Pl Physiol Pl 
Molecular Bio41: 55-75.

Marschner M (1995) Mineral nutrition of higher plants. Academic Press,London.

Mian M A R and Nafziger E D (1994) Seed size and water potential effects on germination and seedling growth of winter wheat. Crop Sci34: 169-171.

Mohammadi M (2011) Effects of kernel weight and source-limitation on wheat grain yield under heat stress. African J Biotech11: 2931-37.

Morizet T, Pollucsck M and Togola D (1983) Drought tolerance in four maize varieties. Field Crops Abst39: 306.

Movahhedy-Dehnavy M, Modarres-Sanavy S A M and MokhtassiBidgoli A (2009) Foliar application of zinc and manganese improves seed yield and quality of safflower (Carthamus tinctorius L.) grown under water deficit stress. Ind Crop Prod30: 82-92.

Mujeeb-Kazi A and Diaz de Leon JL (2002) Conventional and alien genetic diversity for salt tolerant wheats: focus on current status and new germplasm development. In: Ahmad R, Malik KA, (eds.) Prospects for saline agriculture Dordrecht: Kluwer Academic Publishers 37: 69-82.

Munir N, Aftab F (2011) Enhancement of salt tolerance in sugarcane by ascorbic acid pretreatment. Afr J Biotech 10: 18362-370.

Munns R (2005) Genes and salt tolerance: bringing them together. New Phytol167: 645-63.

Nagarajan S (2005) Can India produce enough wheat even by 2020 . Current Sci 89:146771.

Nilson E T and Orcutt D M (1996) Water limitation. In "The physiology of plants under stress" (Nilson, E.T. and Orcutt, D.M., eds.). Wiley and Sons, Inc., New York.

Noreen S, Ashraf M, Hussain M and Jamil A (2009) Exogenous application of Salicylic acid enhances antioxidative capacity in salt stressed sunflower (Helianthus annus L.) plants. Pak J Bot41: 473-79.

Ondrasek G, Rengel Z, Romic D, Poljak M and Romic M (2009) Accumulation of non/essential elements in radish plants grown in salt-affected and cadmium contaminated environment. Cereal Res Comm37:9-12.

Oosterhuis D M and Cartwright P M (1983) Spike differentiation and floret survival in semidwarf spring wheat as affected by water stress and photoperiod. Crop Sci23: 711-717.

Ouda S A E, Mohamed S G, Khalıl F A (2008) Modeling the Effect of Different Stress Conditions on Maize Productivity Using Yield-Stress Model. Int J Natural Eng Sci. 2:57-62.

Pande M and Sharma M (2010) Climate change: Potential impact on chickpea and pigeonpea diseases in the rainfed Semi-Arid Tropics (SAT). (In) 5th International Food Legume Research Conference (IFLRCV) and 7th Europian Conference on Grain Legumes (AEP VIII), April 26-30, Antalya, Turkey.

Pant J, Rerkasem B, Noppakoonwong R (1998) Effect of water stress on the boron response of wheat genotypes under low boron field conditions. Pl Soil202: 193-200.

Parida A K, Das A B, Mohanty P (2004) Defense potentialsto $\mathrm{NaCl}$ in a mangrove, Bruguiera parviflora:Differential changes of isoforms of some antioxidativeenzymes. $\mathrm{J} \quad \mathrm{Pl}$ Physiol161: 531-542.

Passioura J (2007)The drought environment: physical, biological and agricultural perspectives. J Exp Bot581:13-117.

Patel J J, Mevada K D and Chotaliya R L (2003) Response of summer mungbean to date of sowing and level of fertilizers. Indian $\mathbf{J}$ of Pulses Research 16 (2): 122-4.

Peleg Z, Saranga Y, Yazici A, Fahima T, Ozturk L and Cakmak I (2008) Grain zinc, iron and protein concentrations and zinc-efficiency in wild emmer wheat under contrasting irrigation regimes. Pl Soil306: 57-67.

Peng S, Huang J, Sheehy J E, Laza R C, Visperas R M, Zhong X (2004) Rice yields decline with higher night temperature from global warming. Proc Nat Acad Sci101:99719975.

Peterson C M, Klepper B, Pumphrey F B and Rickman R W (1984) Restricted rooting decreases tillering and growth of winter wheat. Agron J 76: 861-863.

Phap V A (2006) Induction of salt tolerance in rice (Oryza sativa L.) by brassinosteroids. 
Ph.D dissertation. Bonn Univ, Germany.

Pramanik S C and Singh N B (2008) Boost pulse production through new planting techniques. Indian Farming 58 (1): 4-6.

Prasad R (2012) Textbook of Field Crops Production-Food Grain Crops. 1: 248319. Indian Council of Agricultural Research, New Delhi.

Ramadan H A, Al-Niemi S N and Hamdan T T (1985) Water stress, soil type and phosphorus effects on corn and soybean. Iraqi J Agri Sci3: 1237-144.

Rao S S R, Vardhini B V, Sujatha E and Anuradha S (2002) "Brassinosteroids-A new class of phytohormones." Current Sci82: 1239-45.

Razmjoo K, Heydarizadeh P and Sabzalian M R (2008) Effect of salinity and drought stresses on growth parameters and essential oil content of Matricaria chamomile. Int J Agric Biol 10: 451-54.

Reddy A A (2006) Impact assessment of pulses production technology, Research Report No 3, Indian Institute of Pulses Research, Kanpur, Uttar Pradesh, India.

Reddy M M, Rao L J and Latha A M (2007) Influence of dates of sowing on growth and yield of mungbean (Phaseolus radiatus) and urdbean (Vigna mungo) during summer in Alfisols. Journal of Research, ANGRAU 35 (4): 19-23.

Rickman R W, Klepper B L and Peterson C M (1983) Time distribution for describing appearance of specific culms of winter wheat. Agron J 75: 551-556.

Rivero R M, Kojima M, Gepstein A, Sakakibara H, Mittler R, Gepstein S, Blumwald E (2007) Delayed leaf senescence induces extreme drought tolerance in a flowering plant. Proc Natl Acad Sci USA104: 1963119636

Rizza F, Badeck FW, Cattivelli L, Lidestri O, Di Fonzo N and Stanca A M (2004) Use of a water stress index to identify barley genotypes adapted to rainfed and irrigated conditions. Crop Sci44: 2127-2137.

Roy H K and Kumar A (1990) Effects of potassium on yield of maize and uptake and forms of potassium. Ind J Agric Sci62:76264.

Ruellanda E and Zachowski A (2010) How plants sense temperature. Env Exp Botany69:225232.

Sacks M M, Silk W K and Burman P (1997) Effect of water stress on cortical cell division rates within the apical meristem of primary roots of maize. Pl Physiol 114: 519-27.

Sairam R K (1994) Effect of homobrassinolide application on metabolism and grain yield under irrigated and moisture-stress conditions of two wheat varieties. Pl Growth Regulation14: 173-81.

Sairam R K and Srivastava G C (2002) Changes in antioxidant activity in sub-cellular fraction of tolerant and susceptible wheat genotypes in response to long term salt stress. Pl Sci 162: 897-904.

Sairam R K, Roa K V and Srivastava G C (2002) Differential response of wheat cultivar genotypes to long term salinity stress in relation to oxidative stress, antioxidant activity and osmolyte concentration. $\mathrm{Pl}$ Sci163: 1037-1048.

Salam A P A, Hollington P A, Gorham J, Wyn Jones R G and Gliddon C (1999) Physiological genetics of salt tolerance in wheat (triticum aestivum 1.): performance of wheat varieties, inbred lines and reciprocal F1 hybrids under saline conditions. J Agron Crop Sci183:145-56

Schneekloth J P, Klocke N L, Hergert G W, Martin D L and Clark R T (1991) Crop rotations with full and limited irrigation and dryland management. Trans ASAE 34: 2372-2380.

Schneekloth J, Bauder T and Hansen N (2012) Limited irrigation management: principles and practices. http://www.ext.colostate.edu/pubs/crops/04 720.html.

Segele Z and Lamb P (2005) Characterization and variability of Kiremt rainy season over Ethiopia. Meteor Atmos Phys 89:153-180.

Sehrawat N, Yadav M, Bhat K V, Sairam R K and Jaiwal P K (2015) Effect of salinity stress on mungbean during consecutive summer and spring seasons. Journal of Agricultural Sciences 60(1): 23-32.

Seleshi Y and Camberlin P (2006) Recent changes in dry spell and extreme rainfall events in Ethiopia. Theor Appl Climatol83:181-191. 
Senaratna T, Touchell D, Bunn E and Dixon K (2000) Acetyl salicylic acid (Aspirin) and salicylic acid induce multiple stress tolerance in bean and tomato plant. Pl Growth Regul30:157-61.

Serraj R, McNally K L, Slamet-Loedin I, Kohli A, Haefele S M, Atlin G and Kumar A (2011) Drought resistance improvement in rice: An integrated genetic and resource management strategy. Pl Prod Sci14: 1-14.

Serrano R, Mulet J M, Rios G, Marquez J A, de Larrinoa I F, Leube M P, Mendizabal I, Pascual-Ahuir A, Proft M, Ros R and Montesinos C (1999) A glimpse of the mechanisms of ion homeostasis during salt stress. J Exp Bot50:1023-36

Shahzad A, Ahmad M, Iqbal M, Ahmed I and Ali GM (2012) Evaluation of wheat landrace genotypes for salinity tolerance at vegetative stage by using morphological and molecular markers. Gene Mol Res 11: 679-92.

Shakirova F M, Sakhabutdinova A R, Berzukova M V, Fatkhutdinova $\mathrm{R} A$ and $\mathrm{D}$ R Fatkhutdinova (2003) Changes in the hormonal status of wheat seedlings induced by salicylic acid and salinity. Plant Sci164: 317.

Shannon M C and Grieve C M (1999) Tolerance of vegetable crops to salinity. ScientiaHort78: 5-38.

Sharma K D, Pannu R K and Behl R K (2007) Effect of early and terminal heat stress on biomass partitioning, chlorophyll stability and yield of different wheat genotypes. Proc: The international conference on sustainable crop production in stress environment: Management and genetic options. $\quad \mathrm{Pp}$ 187-94.Agrobios (International), Jodhpur.

Sharma P N, Chatterjee C, Agarwala S C and Sharma C P (1990) Zinc deficiency and pollen fertility in maize (Zea mays). Pl Soil124:221-225.

Sharma P N, Chatterjee C, Agarwala S C and Sharma C P (1990) Zincdeficiency and pollen fertility in maize (Zea mays). Pl Soil 124: 221-225.

Sheng F and Xiuling C (2004) Influence of atmospheric precipitation on soil leaching and desalinization in Semi Humid region.
Academic Press, Beijing, Peoples Republic of China.

Shereen A, Mumtaz S, Raza S, Khan M A and Solangi S (2005) Salinity effects on seedling growth and yield components of different inbred rice line. Pak J Bot37: 13139.

Shi J F, Mao X G, Jing R L, Pang X B, Wang Y G, and Chang X P (2010) Gene expression profiles of response to water stress at the jointing stage in wheat. Agric Sci China9: 325-330.

Shimono H, Hasegawa T and Iwama K (2002) Response of growth and grain yield in paddy rice to cool water at different growth stages. Field Crops Res73: 67-79.

Steponkus P L, Uemura M and Webb M S (1993) Acontrast of the cryostability of the plasma membrane of winter rye and spring oat-two species that widely differ in their freezing tolerance and plasma membrane lipid composition. In: STEPONKUS, P.L. ed. Advances in Low-Temperature Biology. London, JAI Press, 2: 211-312.

Thakur P S and Rai V K (1984) Water stress effects on maize growth responses of two differentially drought sensitive maize cultivars during early stage of growth. Indian Journal of Ecology 11:92-98.

Tikhomirova E V (1985) Changes of nitrogen metabolism in millet at elevated temperatures. Field Crops Res11: 259-64.

Todd R W, Klocke N L, Hergert G W and Parkhurst A M (1991) Evaporation from soil influenced by crop shading, crop residue, and wetting regime. Trans ASAE34: 461-466.

Trofimova M S, Andreev I M and Kuznetsov V V (1999) Calcium is involved in regulation of the synthesis of HSPs in suspension cultured sugar beet cells under hyperthermia. Physiol P1105: 67-73.

Tuberosa R, Salvi S (2006) Genomics-based approaches to improve drought tolerance of crops. Trends Pl Sci11: 405-412.

Tuna A L, Kaya C, Higgs D, Murillo-Amador B, Aydemir S and Girgin A R (2008) Silicon improves salinity tolerance in wheat plants. Environ Exp Bot62:10-16.

Turner N C, O'Toole J C, Cruz R T, Namuco O S and Ahmad S (1986) Responses of seven 
diverse rice cultivars to water deficits: I. Stress development, canopy temperature, leaf rolling and growth. Field Crops Res13: 257-271.

Uhart S A and Andrade F H (1995) Nitrogen deficiency in maize: I. Effects on crop growth, development, dry matter partitioning, and kernel set. Crop Science 35:1376-83.

Valentovic P, Luxova M, Kolarovic L and Gasparikova O (2006) Effect of osmotic stress on compatible solutes content, membrane stability and water relations in two maize cultivars. Pl Soil Environ52: 186-191.

Verma U N, Pal S K, Singh M K and Thakur R (1997) Productivity, energetics and competition function of wheat (Triticum aestivum L.) plus Indian mustard (Brassica juncea L.) intercropping under varying fertilizer level. Indian J Agron 42: 201-204.

Wahid A, Gelani S, Ashraf M and Foolad M R (2007) Heat tolerance in plants: an overview, Environ. Exp. Bot. 61:199-223.

Wang S G (1997) Influence of brassinosteroid on rice seedling growth" Inter Rice Res Notes22: 20-21.

Wang S, Qian X, Han B P, Luo L C, Hamilton D $P$ (2012) Effects of local climate and hydrological conditions on the thermal regime of a reservoir at Tropic of Cancer, in southern China. Water Res 46: 2591-2604.

Waseem M, Habib A and Ashraf M (2006) Effect of salicylic acid applied through rooting medium on drought tolerance of wheat. Pak J Bot38: 1127-36.

Webb A A R, McAinsh M R, Taylor J E and Hetherington A M (1996) Calcium ions as intercellular second messengers in higher plants. Av Bot Res22: 45-96.

Wei X R, Hao M D, Zhang C X and Wang X G (2005) Effects of zinc and manganese fertilizers on maize photosynthetic performance under soil drought condition (in Chinese). Acta Agron Sin31: 11011104.

Westgate M E and Boyer J S (1986) Reproduction at low and pollen water potentials in maize. Crop Sci26: 951-956

Wu Y and Cosgrove D J (2000) Adaptation of roots to low water potentials by changes in cell wall extensibility and cell wall proteins. J Exp Bot51:1543-53.

Yeo A R and Flowers T J (1983) Varietal differences of sodium ions in rice leaves. $\mathrm{Pl}$ Physiol59: 189-95.

Yoshida S (1981) Fundamentals of rice sciences. International Rice Research Institute, Manila, Phillipes.

Zeng L, Shannon M C, Lesch S M (2001) Timing of salinity stress affects rice growth and yield components. Agric Water Manag48: 191-206.

Zhang X Y, Chen S Y, Liu M Y, Pei D, and Sun H.Y (2005) Improved water use efficiency associated with cultivars and agronomic management in the North China Plain. Agron J 97:783-90.

Zhu J K (2002) Salt and drought stress signal transduction in plants. Annu Rev Pl Bio53: 247-73.

Zimmermann S and Sentenac H (1999) Plant ion channels: from molecular structures to physiological functions. Curr Opin Plant Biol2:474-82.

\section{How to cite this article:}

Kang, J.S., Harmeet Singh, Gurbir Singh, Harrajdeep Kang, Vajinder Pal Kalra and Jagroop Kaur. 2017. Abiotic Stress and Its Amelioration in Cereals and Pulses: A Review. Int.J.Curr.Microbiol.App.Sci. 6(3): 1019-1045. doi: https://doi.org/10.20546/ijcmas.2017.603.120 